Article

\title{
Fast, Feast and Feminism: Teaching Food and Gender in Italian Religious Women's Writings
}

\author{
Danielle Callegari
}

French \& Italian, University of California, 507 Sproul Hall, Davis, CA 95616, USA; dcallegari@ucdavis.edu

Received: 1 November 2017; Accepted: 6 February 2018; Published: 10 February 2018

\begin{abstract}
In the wake of Caroline Walker Bynum's essential studies on the crucial role food played in the lives of medieval religious women, significant attention has been given to the connection between premodern women's spiritual practices and eating practices. However, the relationship between religious women and food is not limited to body manipulation, inedia or eucharistic frenzy. Indeed, recent critical work has provided accessible translations and critical apparatus necessary for an exploration of food and women's religiosity that builds on Bynum's rich foundation and examines the many ways in which women expressed themselves through food, both material and metaphoric. This approach not only allows students to engage with women's writing through the familiarity and universality of food, but moreover reminds them of the real, living, breathing women behind the texts, thus opening the door to a feminist rereading of texts-not as proto-feminist themselves, but rather in the re-valuing of the substantial contributions of their female authors, who had subtle social awareness, public professional pursuits, and complex and varied relationships with God.
\end{abstract}

Keywords: convents; food; early modern; gender; Italian; medicine; medieval; pharmacy; women

\section{From Holy Anorexia to a Feminist Fast}

In his seminal study on Italian religious women from the Middle Ages to the present, Holy Anorexia, Rudolph Bell revealed a common theme in the lives of women on the peninsula across the ages: a desire to eliminate food and purge their bodies entirely from the need to consume. Translating a passage on the fasting behavior of the medieval Italian mystic Catherine of Siena, as recounted by her confessor Raymond of Capua, Bell distilled a vision of the relationship between premodern women and food that would prove lasting:

As we have said above, her stomach could digest nothing and her body heat consumed no energy; therefore anything she ingested needed to exit by the same way it entered, otherwise it caused her acute pain and swelling of her entire body. The holy virgin swallowed nothing of the herbs and things she chewed; nevertheless, because it was impossible to avoid some crumb of food or juice descending into her stomach and because she willingly drank fresh water to quench her thirst, she was constrained every day to vomit what she had eaten. To do this she regularly and with great pain inserted stalks of fennel and other plants into her stomach, otherwise being unable to vomit. Because of her disparagers and particularly those who were scandalized by her fasting, she maintained this life-style until her death [about six years later].

(Bell 1985, pp. 27-28)

The grotesque inversion of the meal here is striking to the first time reader, especially the new student unfamiliar with the tropes and hyperbolic self-representations of the pre and early modern world. Moreover, this extreme portrait is often the only one to which students are given access. While most students of the Italian Middle Ages encounter the starving mystic, many are never offered another 
narrative that proposes a different possible relationship between women and food going forward. Though the work of Caroline Walker Bynum has brought attention to the broader dynamics of gender roles and mediation at play in the figure of the medieval female mystic, but despite Bynum's insistence on food as presence and power, modern audiences often remain focused specifically on how women starved themselves, rather than how they used food to communicate and self-define.

Yet the rejection of food, as Bynum asserts, was available to women as a tool precisely because they knew food so well, spent so much time with it, and controlled its presence: "[Food] was also a particularly obvious and accessible symbol to women, who were more intimately involved than men in the preparation and distribution of food" (Bynum 1987, p. 30). Nor was it an arbitrary choice among material possibilities. In a world defined by significant obstacles to food access and the persistent threat of famine, food was not just a fundamental material concern to premodern people; its distribution, preparation, and consumption were the activities on which pre and early modern life were centered. Manipulation of food and diet became a powerful tool for medieval and Renaissance self-fashioning, through the collectively accepted role it played in both secular and religious culture. Hunger and eating were so overwhelmingly the focus of life that they took the place of or became the expression of other preoccupations or concerns: "When we look at what medieval people themselves wrote, we find that they often spoke of gluttony as the major form of lust, of fasting as the most painful renunciation, and of eating as the most basic and literal way of encountering God" (Bynum 2008, pp. 138-39). Women thus used food because it was their territory, and because it spoke volumes to the larger community.

The connection between anorexia nervosa and "holy anorexia" has been challenged and troubled, but the relationship between daily interaction with food and its socially constructed values has been given much less attention. An examination of the latter is, however, now possible, thanks to the wealth of religious women's writing that has been made available in new editions and translations in recent decades. Though it has often been in the context of wider studies or work dedicated to other preoccupations, scholars of medieval and early modern Italian religious women have in fact already uncovered and provided much evidence of the rich and varied relationship their subjects had with food. Contemporary students need not stretch their imagination nor dig into the archives to reach an understanding of these women and their religious lifestyles. The intimate relationship with food, as a symbol or as fulfillment of a physical need, is what binds all people together across time and place, and it continually presents itself in the historical evidence and creative works of women-even those best known for their distance from food. Looking back at the Italian women in pre and early modern Europe who have been so thoroughly examined for their inedia, this essay will take as its point of departure not the rejection of food but rather the relationship with food more generally-from cooking to healing to provisioning. It will consider examples both of famous "holy anorexics" like Angela of Foligno (1248-1309) and Catherine of Siena (1347-1380), but also of less noted names, like the Bolognese Dominican nun Diodata Malvasia (ca. 1533-post 1617), and their convents, which provide a window into larger female religious communities. In sampling this spectrum it becomes clear that women used food as their society did, to express and manipulate social norms, navigate negotiations, and construct communities. Through these examples it is also possible to understand how women exploited their special relationship with food as the primary nourishers and preparers in order to speak to a wider audience — one that included their female peers, who could in turn use food to similar ends.

\section{Women Eaters}

The cultural imagination of premodern Europe is a landscape of asceticism, solitude, and lean times in cold palaces, almost inevitably lending itself to a focus on abstinence and lack. This is not necessarily a misinterpretation of the contemporary reality, as demographic, meteorologic, and technological conditions determined that most medieval European people lived in an almost constant fear of deprivation that improved only at the very end of the early modern period. However, it has frequently led to erroneous conclusions and extrapolations. The scarcity or perceived scarcity 
of food neither diminished its power to convey meaning, nor its metaphoric omnipresence. On the contrary, while Jacques Le Goff termed the late medieval European continent a "universe of hunger," he was describing a universe fraught by hunger but also charged by it, a hunger that fed a more powerful obsession with food (Le Goff 1964, p. 290). In a world where dearth and starvation loomed large, food and food economies became a primary means for enforcing power systems, organizing community structures, and defining the self.

In the complex political landscape of premodern Italy, as the population surged and shifted into urban contexts, food was attentively, even maniacally controlled by local leaders, who understood that ensuring the constant flow of food into their respective cities was not simply a moral obligation but perhaps their only means of survival. The volatile political climate meant that cities were often involved in skirmishes, under siege, or facing provocations and unrest from within. Hostilities and wars among the emerging communes were focused strongly on food: maintaining it for oneself and denying access or destroying the food supplies of one's enemy. As George Dameron has recently confirmed, in the political and economic climate of the central Italian communes of the thirteenth and early fourteenth centuries, "access to a steady and dependable supply of food was absolutely essential for growth, stability, and political legitimacy" (Dameron 2017, p. 985). ${ }^{1}$ A reliable provider of food could expect to hold power over a stable and productive city, but even the perception of an approaching dearth could be enough to lose control.

The threat of impending famine and increased competition for food heightened its relational significance, and led to an elaboration of the social and political values associated with edible items in pre and early modern Italy, as Ken Albala has illustrated (Albala 2002, pp. 186-87). Allen Grieco has further underlined that during the late Middle Ages and early Renaissance in Italy, "food was a primary element of distinction", and what one ate was inextricably connected to who one was, or who one was seen to be (Grieco 1996, p. 372). Following the pattern of the great chain of being, all foods could be placed on a hierarchical ladder, and as all of God's creations, equally good but nonetheless different, could be placed on the ladder distinguishing their proximity to the divine. ${ }^{2}$ Foods of great strength and nobility were meant for powerful men of high rank, just as humble men were drawn to humble foods. Women, less complete and less competent according to the Aristotelian model (De generatione animalium 767b7-9), were expected to consume foods becoming of both their station and their gender. Through this complex scheme in which physiological types were associated with certain types of edible items, men and women of varying class and status organized themselves and created a gastronomic language through which they expressed this social organization. Anything from religious ritual to political negotiation could be carried out through the preparation, exchange, or consumption of food.

This gastro-social hierarchy was reinforced and complicated with the knowledge that food was the means by which to obtain and maintain both a healthy body and a sound mind. For the premodern world, wellness was entirely dependent on a balanced diet. The Galenic texts that gave life to an explosion of interest in the study of medicine in medieval and early modern Italy provided a guide to health based on the management of the four humors contained within the human body: black bile, yellow bile, blood, and phlegm. These fluids influenced physiological and psychological temperament, which could tend toward wet or dry, hot or cold, and create melancholic, choleric, sanguine, or phlegmatic dispositions. The human body thrived when its humors were balanced, a precarious science that demanded constant attention to control and avert the tendency towards

1 I thank George Dameron for providing me with an advance copy of his now available Speculum article on grain economy and politics in the Tuscan communes from the twelfth to the fourteenth centuries (Dameron 2017). His study demonstrates the essential role of food and especially grain in the determination of power structures and the success of cities like Florence in the late Middle Ages.

2 Beyond the classic study by (Lovejoy 1936, pp. 67-98), Grieco has himself more recently provided a very useful summary in (Grieco 1996, pp. 371-80, esp. p. 376, Figure 1). 
an excess or lack of heat and moisture. The introduction of food into the body affected humoral balance, thus diet was both prevention and cure; it would respond to shifts in physical needs according to seasons, age, and illness. ${ }^{3}$ All ills could be treated and perhaps cured by a carefully designed meal plan that included the appropriate foods to control humors. Maintaining the proper levels of heat and cold and moisture and dryness required attention first to one's own disposition-a natural inclination derived from gender and birth place and time-and then to the qualities of foreign substances introduced into or surrounding the body. Each individual required food (understood as both sustenance and medicine) that matched and suited their temperament and complexion, as dictated by their humoral tendencies. For women, naturally damp and cold as Aristotle had determined, and prone to anger or hysteria, diet was of especially crucial importance (De generatione animalium 766a-b).

Through these lenses, food became the ultimate signifier, and abstinence from it was just one of several ways to use its meaning. The many values of food and the many roles it played in everyday life were not lost to women as a result of their gender, and their writings and activities reflect this. While blood frenzy and living on the eucharist alone might stand out to the modern reader as the most striking and thus most attention-worthy of dietary habits, they were not the average points of contact between women and food, even in the context of the premodern cloistered religious community. In fact, the interaction most religious women had with food was significantly more nuanced and decidedly less extreme. They were engaged in the banalities of day to day living and, like all humans, used food to nourish their bodies and furnish themselves with energy. They cooked and baked to foster a spirit of conviviality in their convent, and also to make money to support and grow their community. They manipulated and experimented with food products to promote health and treat illness, and also to gain stature and access. They capitalized on the social values of food to demonstrate prowess and to earn patronage. Food was intimately tied to their faith, but they consumed it just as often as they abstained from it, and for the same reason-to express love for each other and God. Perhaps most importantly, even when they engaged in extreme fasting, their attention was frequently not on the food they were losing but rather the food that others were gaining as a result of their choice.

\section{Women Cooks}

Even for those who focused on limiting or eliminating food from their own diet, in the premodern world it was the preparation of food that in fact filled the days of most women, religious or secular. Before the advent of kitchen technologies that allowed for basic foodstuffs-in particular bread-to be produced relatively quickly and easily, the act of preparing food for a household or a religious community was a major undertaking. As food historians have frequently observed, the essential change between the premodern and modern existence is that in the premodern moment, most people spent most of their lives obtaining and preparing their daily sustenance. Maintaining a fire hot enough to cook meat and fire bread, milling flours, butchering, and more was all performed at the local or household level, on a schedule set by the seasons and dependent on the availability of manual labor. All individuals, but especially women, directed the vast majority of their energy toward food e.g., (Montanari 2014, pp. 41-47).

Indeed, even the most extreme ascetics include reflections on these frequent, quotidian interactions with food. In her Memoriale, the medieval Italian mystic Angela of Foligno sets her most dramatic scene of temptation over the sink washing lettuce:

Following that exchange of words, on the same day when I was about to wash some lettuce, a certain deceptive voice joined in and said: "What?! Are you worthy to wash lettuce?!" And then, even though I clearly saw the deception, I responded with indignation but also with sadness, because this deception raised in me doubts about other statements that had

3 On the inextricable tie between diet and medicine and the careful attention to humoral science in the Middle Ages see the essential study by (Siraisi 1990, pp. 115-52); as well as the survey of medieval food and cooking by (Scully 1995, pp. 28-65). 
been made. I said, "I'm worthy to be sent to Hell immediately by God; I'm only worthy to gather manure."

(Foligno 1999, p. 56)

Cristina Mazzoni has unpacked this important scene in the context of her larger study of religious women and food that aims to push past the emphasis on starvation (Mazzoni 2005). Mazzoni observes that it is no coincidence that Angela chooses to highlight the simplest of foods and the most tedious of gastronomic operations in this key moment in the revelation of her spiritual progress. It communicates with quick efficiency to her audience several pieces of information: her own femininity and humility in the qualities of the lettuce, humorally moist and damp like women and foods of the poor; the accessibility of her experience, in the universal familiarity of the act of food preparation; the intimacy of her sharing, in the quiet invitation to witness her in her home kitchen. Moreover, Mazzoni rejects that Angela's focus on the preparation of food rather than its consumption is a symptom of her anorexia, pointing to the more obvious fact that it is a practical activity that fits into her role in life, first as a mother and wife and then still, following the death of her family, of herself (Mazzoni 2005, pp. 93-96). Setting her temptation against the backdrop of the act of washing lettuce, Angela is not shining a light on the low caloric content of her diet. Rather, she is drawing attention to her identity as a real, recognizable woman, as expressed through the act of preparing food with her own two hands, and through the collectively understood characteristics of lettuce that reflect her own place in the world.

Mazzoni's insistence that religious women were keenly attuned to the many values of food finds ample evidence in chronicles from and about nuns of the period, who were well known for their prowess in the kitchen. Mario Fanti long ago acknowledged that a significant number of early modern Bolognese convents were in the business of producing sweets, and that they became known for their respective specialities (Fanti 1972, preface). Among the many convents she has examined, Elissa Weaver has noted that a large number of them produced sweets and distillates, and she has specifically referred to the ledgers from Santa Chiara in Pistoia to underline their expenditures on oil, spices, and even meats for holidays, and their income from pigeons and wine (Weaver 2002, pp. 28-29). Wine was a popular item both for consumption and production in convents, and Jutta Gisela Sperling has pointed out that many of the wealthiest Venetian convents she has studied not only received a substantial income in wine, but also bought supplementary wine, reporting a consumption of between 251 and 577 L per capita annually (Sperling 1999, pp. 180-81). In the same context, Mary Laven has brought to light a particularly evocative passage describing the baking habits of women in the Venetian convents she has investigated:

The nuns keep for themselves those gifts which they receive from their homes, without showing them to the Abbess ... Likewise, when they send presents to their relations, they do not inform the Abbess ... and this accounts for half the food which the convent is squandering, because the nuns are continually making biscuits, cakes, doughnuts and pastries in great quantities. And to this end, at certain times of the year, several quarteroli of flour are doled out to the nuns, with the result that they consumed five hundred stara of grain a year, two hundred stara more than they should reasonably expect to use.

(Laven 2002, pp. 109-10)

While these women are a useful point of contrast to Angela in their apparent indulgence, and lack of fear of food, the understanding of the power of food that they share with Angela is perhaps even more relevant. Though the comments of their observers lament their prodigality and secrecy, the nuns were not baking sweets because their lives offered no other pleasure or pastime, nor were they guzzling wine to relieve themselves of their depression or boredom. On the contrary, cloistered women used food and wine in the same way that it was used beyond the convent walls. Sperling analyzes the Venetian convents' ledgers and affirms that the inflated numbers reveal a discrepancy that cannot be 
explained by simple wastefulness or prodigality. Like their wealthy families, these nuns may have overpurchased or distributed copious food as a sign of their own abundance-their ability to give away so much a subtle sign of how much they already had. Mary Laven emphasizes that the "frenzied" baking of cakes at San Zaccaria was undertaken to send back to their relations, as a reminder of their value despite being in the convent, while in 1594 the nuns of Ognissanti in Venice defined the family units within their community by personal food supplies. Through these gastronomic exchanges, the women could assert their presence in their families and in civic society, even as they were locked away, and leverage better connections with other outside relations (Laven 2002, pp. 108-12). Religious women thus showed status, reinforced familial bonds, and garnered favor and attention through food. More than this, they circumvented accepted authority and negotiated their own relationships, affirming their place in the larger community.

\section{Women, Food and Pharmacy}

Italian religious women's engagement with food culture was not limited to the domestic sphere, nor to the traditionally female coded act of home food preparation. Medicines were derived from a knowledge of the Galenic tradition and an elaborate understanding of where edible plant and animal products fell on the humoral spectrum, and marked a place where female familiarity with food overlapped with the public and the professional. Religious women were direct participants in this culture, not only as patients. In convents women often prepared food in its role as medicine, from unguents and ointments to syrups and distillations, to fruit conserves and candies. Carefully studying to learn the humoral properties of foods and incorporate them into medicaments of all kinds, women pressed their imposed social role as preparers of food to become also healers using food.

This is not, to be sure, a suggestion based on speculation, but rather an interest and talent that the women themselves document. In the history of the miraculous icon the Madonna of San Luca that she composed, which also includes lengthy excursions on the history and day to day life of her convent of San Mattia, the sixteenth-century Bolognese Dominican nun Diodata Malvasia recalls having read Galen directly. She did this explicitly to learn about humoral theory and to serve as the nurse of her convent at the order of her superiors, as she elaborates:

So Galen depicted the heroes of virtue in the second book of On the Temperaments, whose excellence was likewise displayed in their beautiful features (through the order of my superiors, I served as nurse, and it thus pleased me to read something of medicine, in order to carry out my duty as best I could).

(Malvasia 2015, p. 82)

Malvasia's affirmation might seem remarkable, and yet, in the context of her work, which includes a chronicle of the accomplishments of her convent over the mid-sixteenth century and a complete history of the Madonna of San Luca, it sits cleanly as one of many impressive achievements directed toward the betterment of her community. Her role as nurse, and her studious preparation for that role, comes as a natural extension of the image she constructs of herself as a leader in a convent of active, competent women-women whom she describes in her convent chronicle as "truly capable of governing a republic, let along a convent" (Malvasia 2015, p. 35)

Moreover, there is extensive evidence of nuns working as healers and pharmacists in early modern Italy, an area of work for religious women that grew in part, as Jutta Sperling has demonstrated, in response to the mid-sixteenth century push for every convent to maintain its own apothecary (Sperling 1999, p. 18). Gianna Pomata's research on nuns acting both as spiritual healers and as medical practitioners in Bologna reveals that Malvasia would have in fact been one of perhaps many religious women familiar with Galenic theory in her city (Pomata 1999, 2005), and thus not even a particular exception in that sense. Further tracing this trend but looking instead at Florence, Sharon Strocchia has reconstructed the vast expansion of nun-apothecaries in the early modern period, revealing an elaborate network of religious women in medicine who maintained important, lucrative pharmacies. Perhaps most strikingly, some convents 
cycled members through the positions of pharmacist and nurse, such that the community as a whole improved and grew a collective body of knowledge and skills that they and later generations could continue to capitalize on together (Strocchia 2011, pp. 638-39). The sophistication of their operations would eventually translate into a profit for their society as a whole while simultaneously providing them with a foothold in the world outside of their cloister walls.

Using food as medicine, nuns took advantage of the opportunity afforded by the growing market for pharmaceutical knowledge and products. They invested in special equipment and apprenticed with established experts in order to set themselves apart and lift themselves out of a potentially marginal existence in the cloister. As Strocchia points out, "Renaissance religious women both augmented the medical resources available in Italian urban society and acquired roles of public significance beyond the spiritual realm" (Strocchia 2011, p. 627). Through their impressive medical learning and the quality of their products, these women created a public profile that allowed them not only to guarantee success in their immediate endeavor, but become vital participants in —even guarantors of - the health of the community well into the future.

\section{Women Nourishers}

Finally, it is important to observe that even when women were indeed focused on extreme fasting and the elimination of food from their lives-even when they thought of food as loathsome and terrifying and preferred, as in the case of Catherine of Siena, to dine on the pus of a leper than on prepared delicacies - their efforts were frequently very consciously geared toward the act of nourishment. This nuance is often noted but rarely is it taken seriously by a modern audience, perhaps because in male religiosity the desire for food remained the more recognizable of struggles, and its deliberate but balanced rejection the hardest resolution. Food has always been man's real trial, because, as Maggie Kilgour has observed, "food is a temptation that must be constantly encountered, even after conversion" (Kilgour 1992, p. 49). Unlike its lustful counterpart, food cannot simply be eliminated from one's life. Even Augustine, getting closer to his fully converted self, lamented:

In the midst of these temptations I struggle daily against greed for food and drink. This is not an evil which I can decide once and for all to repudiate and never to embrace again, as I was able to do in the case of fornication. I must therefore hold back my appetite with neither too firm nor too slack a rein

(Confessions 10.31)

The bishop of Hippo, though better known for his struggle to reach chastity, was nonetheless overwhelmed by his fear of food and the constant menace of gluttony that was the result of the very inappropriateness of eliminating food all together. True conversion included recognizing eating as an essential component of human life imposed by God on man. On the contrary, for premodern religious women the problem seems to have been more often not how to give up food, but how to give up giving up food. These women, as Bynum has observed, were often rebuked for eating too little and purposely doing harm to themselves. ${ }^{4}$ Food was not meant to be eliminated; fasting was a tool, not a goal in itself, and a diet that injured or threatened to destroy the body bestowed by God was a sinful one. But if, as highlighted earlier, Raymond of Capua called attention to Catherine's utter inability to eat, the writings in Catherine's own voice turn to the question of how to direct a fast to its proper purpose. Fighting her own tendency toward violent asceticism, in her letters Catherine also reminded other women to use fasting as an "instrument," meant to "kill the will, not the body" (Tylus 2009, p. 221). Bynum reiterates this, confirming that for the medieval mystics, "insatiable, devouring hunger

4 Bynum points out that religious men frequently rebuked their female counterparts for "unbecoming" or "unsuitable" fasting in (Bynum 1987, esp. pp. 73-112). 
is evil, desire run out of control [...]. But if human hunger is controlled, it will be met with the bread of heaven, new flesh to redeem the flesh of Adam" (Bynum 1987, p. 40)

Indeed in her works Catherine reveals she saw an opportunity in fasting akin to the one Augustine eventually elaborated in response to the problem of striking the right balance with food. As Augustine underlined, the defect of human nature is not the practice of consuming generally, a necessity that sustains our bodies and allows us to imitate in the city of man the great feast to be enjoyed in the city of God; the error is in indulging the craving for food too frequently or too extravagantly and, most saliently, at the expense of others. Not severe abstinence but a frugal lifestyle, Augustine proposed, ensures one does not engage in gluttony, and the left over food will be stored for the hungry Christ in heaven (Sermo 210).

Catherine, however, rewrote this narrative, with a female protagonist at its center. In conquering bodily needs, and rejecting the desire for food, the soul became more like a "donna" — not a simple "femina," or female, but a woman with seigniorial connotations. Through this transformation, permitted by denying the body, the soul became prepared to act like a leader: "a donna from whom no one can remove the signoria or leadership unless she wills it herself" (Tylus 2009, p. 119). Catherine went so far as to advise the Sienese senator Andreasso Cavalcabuoi that conquering the body would allow his soul to be free and a donna, and as a donna it would then be responsible "to take good care of one's city" (Tylus 2009, pp. 118-19). In this way Catherine demonstrated that a fruitful fast did not reject food all together, but rather directed it away from the self and toward a lacking neighbor. It is interesting to note that the iconic portrait of Catherine by Andrea Vanni (ca. 1400) shows her placing her stigmatized hand on the mouth of the penitent kneeling before her, at least vaguely conjuring a scene of the distribution of the Eucharist, further supported by the pose of the penitent. It is a gesture that enacts Catherine's uncanny ability to translate her self-denial into nourishment for another, just as her letters sustained her followers in her absence. The Vanni portrait, Jane Tylus explains, illustrates precisely how charity comes into fruition as Catherine feeds and then gives birth to good deeds through her "prossima" (Tylus 2009, pp. 176-77). The food that came out of her own mouth went into that of another, allowing the community to grow on the shared sustenance.

\section{Conclusions}

From late medieval letters to late Renaissance convent chronicles, there is a satisfying breadth and diversity of texts authored by or featuring Italian religious women interacting with food. Taken together, these texts provide nuanced contours to the portrait of pre and early modern religious women. Even in the case of their extreme asceticism, women were not changing expectations and breaking rules within the simple binary of conforming or undermining. Unlike the secular "diet", which inures the contemporary mindset to the many varied meanings of food and often implies gender and status conformity, the diet of pre and early modern religious women was one of directed significance, a choice to use their bodies and the material they knew best to enact change. When Margaret of Cortona famously said "I want to die of starvation to satiate the poor," she announced a sacrifice that could not but seem violently extreme, and yet, her death was not the focus of her efforts. The food she did not consume would save others: her delight was in the power of her death to nourish many lives.

As the texts sampled here reveal, translations and modern critical editions are now available and easily accessible thanks to the collaboration of publishers and scholars over recent decades, working together to bring to light the voices of women who did not witness themselves as marginalized. Through these efforts, students can now access and develop a connection with these women, to understand them not only as abstinents or extremists, but also as consumers and strategists. This approach allows students to engage with medieval and early modern Italian religious women's writing, but more importantly it puts them into contact with the substantial contributions of real women with real voices, through the familiarity and universality of food.

Conflicts of Interest: The author declares no conflict of interest. 


\section{References}

Albala, Ken. 2002. Eating Right in the Renaissance. Berkeley: University of California Press.

Bell, Rudolph. 1985. Holy Anorexia. Chicago: University of Chicago Press.

Bynum, Caroline Walker. 1987. Holy Feast and Holy Fast: The Religious Significance of Food to Medieval Women. Berkeley: University of California Press.

Bynum, Caroline Walker. 2008. Fast, Feast, Flesh: The Religious Significance of Food to Medieval Women. In Food and Culture: A Reader, 2nd ed. Edited by Carole Counihan and Penny Van Esterik. New York: Routledge, pp. 138-58.

Dameron, George. 2017. Feeding the Medieval Italian City-State: Grain, War, and Political Legitimacy in Tuscany, c. 1150-c. 1350. Speculum 92: 976-1019. [CrossRef]

Fanti, Mario. 1972. Abiti e Lavori delle Monache di Bologna in una Series di Disegni del Secolo XVIII. Bologna: Tamari. Foligno, Angela. 1999. Memorial. Edited by Cristina Mazzoni. Translated by John Cirignano. Cambridge: D.S. Brewer. Grieco, Allen J. 1996. Alimentazione e classi sociali nel tardo Medioevo e nel Rinascimento in Italia. In Storia Dell'alimentazione. Edited by Jean Flandrin and Massimo Montanari. Rome: Laterza.

Kilgour, Maggie. 1992. From Communion to Cannibalism: An Anatomy of Metaphors of Incorporation. Princeton: Princeton University Press.

Laven, Mary. 2002. Virgins of Venice: Broken Vows and Cloistered Lives in the Renaissance Convent. New York: Penguin. Le Goff, Jacques. 1964. La Civilisation de l'occident Médiéval. Paris: Arthaud.

Lovejoy, Arthur. 1936. The Great Chain of Being: A Study of the History of an Idea. Cambridge: Harvard University Press. Malvasia, Diodata. 2015. Writings on the Sisters of San Luca and their Miraculous Madonna. Edited and Translated by Danielle Callegari and Shannon McHugh. Toronto: Iter Academic Press and Tempe, AZ; CMRS.

Mazzoni, Cristina. 2005. The Women in God's Kitchen: Cooking, Eating, and Spiritual Writing. New York: Continuum. Montanari, Massimo. 2014. Gusti del Medioevo: I Prodotti, la Cucina, la Tavola. Rome: Laterza.

Pomata, Gianna. 1999. Practicing between Earth and Heaven: Women Healers in Seventeenth-Century Bologna. Dynamis 19: 119-43. [PubMed]

Pomata, Gianna. 2005. Medicine delle monache. Practiche terapeutiche nei monasteri femminili di Bologna in età moderna. In I Monasteri Femminili come Centri di Cultura fra Rinascimento e Barocco. Edited by Gianna Pomata and Gabriella Zarri. Rome: Edizioni di Storia e Letteratura, pp. 331-63.

Scully, Terrence. 1995. The Art of Cookery in the Middle Ages. Woodbridge: Boydell.

Siraisi, Nancy. 1990. Medieval and Early Renaissance Medicine: An Introduction to Knowledge and Practice. Chicago: University of Chicago Press.

Sperling, Jutta Gisela. 1999. Convents and the Body Politic in Late Renaissance Venice. Chicago: University of Chicago Press. Strocchia, Sharon. 2011. The Nun Apothecaries of Renaissance Florence. Renaissance Studies 25: 627-47. [CrossRef] Tylus, Jane. 2009. Reclaiming Catherine of Siena: Literacy, Literature and the Signs of Others. Chicago: University of Chicago Press.

Weaver, Elissa. 2002. Convent Theatre in Early Modern Italy: Spiritual Fun and Learning for Women. Cambridge: Cambridge University Press.

(C) 2018 by the author. Licensee MDPI, Basel, Switzerland. This article is an open access article distributed under the terms and conditions of the Creative Commons Attribution (CC BY) license (http:/ / creativecommons.org/licenses/by/4.0/). 